\title{
Diagnostic accuracy of noncontrast CT imaging markers in cerebral venous thrombosis
}

Pieter-Jan Buyck, MD, * Susanna M. Zuurbier, MD, PhD, * Carlos Garcia-Esperon, MD, * Miguel A. Barboza, MD, Paolo Costa, MD, Irene Escudero, MD, Dimitri Renard, MD, Robin Lemmens, MD, PhD, Nicole Hinteregger, MD, Franz Fazekas, MD, Jordi Jimenez Conde, MD, PhD, Eva Giralt-Steinhauer, MD, PhD, Sini Hiltunen, MD, Antonio Arauz, MD, PhD, Alessandro Pezzini, MD, Joan Montaner, MD, PhD, Jukka Putaala, MD, PhD, Christian Weimar, MD, Leonid Churilov, PhD, Thomas Gattringer, MD, PhD, Hamed Asadi, MBBS, PhD, Turgut Tatlisumak, MD, PhD, Jonathan M. Coutinho, MD, PhD, Philippe Demaerel, MD, PhD, and Vincent Thijs, MD, PhD

Neurology ${ }^{\circledR}$ 2019;92:e841-e851. doi:10.1212/WNL.0000000000006959

\section{Abstract}

\section{Objective}

To assess the added diagnostic value of semiquantitative imaging markers on noncontrast CT scans in cerebral venous thrombosis (CVT).

\section{Methods}

In a retrospective, multicenter, blinded, case-control study of patients with recent onset (<2 weeks) CVT, 3 readers assessed (1) the accuracy of the visual impression of CVT based on a combination of direct and indirect signs, (2) the accuracy of attenuation values of the venous sinuses in Hounsfield units (with adjustment for hematocrit levels), and (3) the accuracy of attenuation ratios of affected vs unaffected sinuses in comparison with reference standard MRI or CT angiography. Controls were age-matched patients with (sub)acute neurologic presentations.

\section{Results}

We enrolled 285 patients with CVT and 303 controls from 10 international centers. Sensitivity of visual impression of thrombosis ranged from $41 \%$ to $73 \%$ and specificity ranged from $97 \%$ to $100 \%$. Attenuation measurement had an area under the curve (AUC) of 0.78 (95\% confidence interval [CI] 0.74-0.81). After adjustment for hematocrit, the AUC remained 0.78 (95\% CI 0.74-0.81). The analysis of attenuation ratios of affected vs unaffected sinuses had AUC of 0.83 (95\% CI 0.8-0.86). Adding this imaging marker significantly improved discrimination, but sensitivity when tolerating a false-positive rate of $20 \%$ was not higher than $76 \%$ (95\% CI $0.70-0.81$ ).

\section{Conclusion}

Semiquantitative analysis of attenuation values for diagnosis of CVT increased sensitivity but still failed to identify 1 out of 4 CVT.

\section{Classification of evidence}

This study provides Class II evidence that visual analysis of plain CT with or without attenuation measurements has high specificity but only moderate sensitivity for CVT.

\author{
Correspondence \\ Dr. Thijs \\ vincent.thijs@florey.edu.au
}

MORE ONLINE

$\rightarrow$ Class of Evidence

Criteria for rating

therapeutic and diagnostic studies

NPub.org/coe

- CME Course

NPub.org/cmelist

\footnotetext{
*These authors contributed equally to this work.

From the Departments of Radiology (P.J.B., P.D.) and Neurology (R.L.), University Hospitals Leuven, Belgium; Department of Neurology (S.M.Z., J.M.C.), Amsterdam University Medical Centers, Amsterdam, the Netherlands; Department of Neurology (C.-G.E.), John Hunter Hospital, University of Newcastle, Australia; Stroke Department (M.A.B., A.A.), Instituto Nacional de Neurología y Neurocirugía Dr. Manuel Velasco Suárez, México City, México; Department of Head and Neck (P.C.), Neurology Unit, Fondazione Poliambulanza, Brescia, Italy; Departments of Head and Neck (P.C.) and Clinical and Experimental Sciences (A.P.), Neurology Clinic, University of Brescia, Italy; Neurology Department (I.E., J.M.), University Hospitals Virgen del Rocio and Macarena, Seville; Neurovascular Lab (I.E., J.M.), Instituto de Biomedicina de Sevilla, Spain; Department of Neurology (D.R.), Nîmes University Hospital, France; Department of Neurosciences (R.L.), Experimental Neurology and Leuven Institute for Neuroscience and Disease (LIND), KU Leuven-University of Leuven; Laboratory of Neurobiology (R.L.), Center for Brain \& Disease Research, VIB, Leuven, Belgium; Departments of Radiology (N.H.) and Neurology (F.F., T.G.), Medical University of Graz, Austria; Department of Neurology (J.J.C., E.G.-S.), Neurovascular Research Group, IMIM-Hospital del Mar, Barcelona; Universitat Autònoma de Barcelona (J.J.C., E.G.-S.), Spain; Department of Neurology (S.H., J.P., T.T.), Helsinki University Hospital, Finland; Department of Neurology (J.M.), Hospital Universitario Virgen Macarena, Seville, Spain; Department of Neurology (C.W.), University Hospital Essen, Germany; The Florey Institute of Neuroscience and Mental Health (L.C.), University of Melbourne; Australia School of Medicine (H.A.), Faculty of Health, Deakin University; Interventional Neuroradiology Service (H.A.), Radiology Department, Austin Health, Melbourne; Interventional Neuroradiology Service (H.A.), Radiology Department, Monash Health, Melbourne, Australia; Department of Clinical Neuroscience/Neurology (T.T.), Institute of Neuroscience and Physiology, Sahlgrenska Academy at University of Gothenburg; Department of Neurology (T.T.), Sahlgrenska University Hospital, Gothenburg, Sweden; Stroke Division, Florey Institute of Neuroscience and Mental Health (V.T.), University of Melbourne, Heidelberg; and Department of Neurology (V.T.), Austin Health, Heidelberg, Australia.

Go to Neurology.org/N for full disclosures. Funding information and disclosures deemed relevant by the authors, if any, are provided at the end of the article.
} 


\section{Glossary}

CTV = CT venography; CVT = cerebral venous thrombosis; DSA = digital subtraction angiography; $\mathrm{H}: \mathrm{H}=$ Hounsfield unit $/$ hematocrit ratio; $\mathrm{HU}=$ Hounsfield units; IADSA = intra-arterial digital subtraction angiography; ICC = intraclass correlation coefficient; $\mathbf{M R V}=$ magnetic resonance venography; $\mathbf{R O C}=$ receiver operating characteristic; $\mathbf{R O I}=$ region of interest.

Cerebral venous thrombosis (CVT), i.e., thrombosis of the intracranial veins and sinuses, is an uncommon cause of stroke. ${ }^{1,2}$ The presentation is highly variable and may consist of headache, seizures, and focal neurologic signs or an altered mental state. Among patients with these neurologic symptoms, the prevalence of CVT is low. ${ }^{3,4}$ Misdiagnosis and delays in diagnosis are not infrequent. ${ }^{5,6}$ To rule out CVT, additional imaging with MRI and magnetic resonance venography (MRV), or with CT venography (CTV), is required. ${ }^{7,8}$ As MRI and MRV are not readily available or rapidly accessible in many institutions and CTV requires contrast agents and is associated with radiation exposure, a less invasive test to rule out CVT is desirable.

Recently, small studies have suggested that noncontrast CT is sufficiently sensitive and specific for the diagnosis of CVT when measurements are made of the attenuation of the dural sinuses and attenuation values are compared with the hematocrit of the patient, in addition to observation of direct and indirect signs of venous thrombosis like hemorrhagic transformation. $^{9-14}$

In this study, we hypothesized that noncontrast CT has high diagnostic accuracy for recent onset CVT. We therefore studied the sensitivity and specificity of noncontrast $\mathrm{CT}$ as compared to MRI or CTV in a large, multicenter study of CVT and controls in the acute phase of CVT (within 48 hours after onset of first symptoms leading to diagnosis) and in the subacute phase of venous thrombosis (between 48 hours to 2 weeks after onset of symptoms).

\section{Methods}

\section{Study population}

We retrospectively enrolled patients with CVT and controls from 10 institutions in Europe and Mexico. We asked sites to identify from their hospital records or CVT databases participants fulfilling the following criteria: at least 18 years old and proven CVT, diagnosed with MRI, CTV, or intra-arterial digital subtraction angiography (IADSA). A noncontrast CT had to be available that was performed because of symptoms that led to the diagnosis of CVT. The CT scan had to have been performed within 2 weeks of symptom onset (headache, seizures, altered mental state, focal neurologic signs). Controls were age-matched ( \pm 5 years) adults who had presented at the same hospitals' emergency departments with (sub) acute headache, focal neurologic findings, seizures, or altered mental state for which noncontrast CT was performed over the same period. In the controls, a diagnosis of CVT had to be ruled out using MRI, CTV, or IADSA or they had to have had a diagnostic workup that led to an alternative diagnosis than CVT.

The Standards for Reporting of Diagnostic Accuracy Studies were followed and the study flowchart is presented in figure 1.

\section{Data collection}

We collected demographic data, presenting symptoms, hematocrit at time of CT, and final diagnosis. In the cases, we collected data on the presence of thrombophilia, defined as protein $\mathrm{C}$ or $\mathrm{S}$ deficiency, antithrombin deficiency, activated protein C resistance or presence of factor V Leiden, PT20210 G-A mutation, or the presence of antiphospholipid syndrome. We recorded transient risk factors for venous thrombosis (pregnancy, puerperium, dehydration, mechanical precipitants, trauma, infections, medication use) and conditions associated with CVT (malignancies, hematologic abnormalities, vasculitis, inflammatory bowel disease, or other inflammatory prothrombotic diseases). No information was collected on side effects associated with performing index or reference standards.

\section{Imaging}

De-identified noncontrast CT scans were centrally collected and were analyzed by 3 experienced readers (reader 1 : a neuroradiologist; reader 2: a stroke fellowship-trained neurologist; reader 3: a final year neurology resident with $\mathrm{PhD}$ in CVT) who were unaware of the case/control status and who did not have access to clinical information or confirmatory MRI/MRV or CT/CTV. The readers judged the presence of venous thrombosis on noncontrast CT based on direct (intracerebral hemorrhage, subdural hemorrhage, cerebral edema, venous infarction) and indirect signs (cord sign, hyperdense sinus). ${ }^{15,16}$ We used the same methodology as the one employed in previous studies. ${ }^{11,13}$ If the reader suspected CVT, he or she measured the attenuation at 3 different locations in the respective sinus by using the cursor. If not, he or she measured the attenuation in 3 random, but different, venous sinuses he or she believed to be reliably differentiated from the surrounding brain parenchyma (figure 2). ${ }^{11}$ Measured densities were documented in Hounsfield units (HU). In addition, the density ratio of affected vs contralateral unaffected venous sinus was calculated by placing a circular region of interest (ROI) within the brightest venous sinus, which was compared to the density within the contralateral ROI. ${ }^{13}$ For patients with sagittal sinus thrombosis or deep CVT, the ROI was compared to the density of the brightest sigmoid sinus. The prespecified abnormal $\mathrm{HU}$ value for diagnosis of CVT was $>62 \mathrm{HU}, \mathrm{HU} /$ hematocrit $(\mathrm{H}: \mathrm{H})$ ratio 


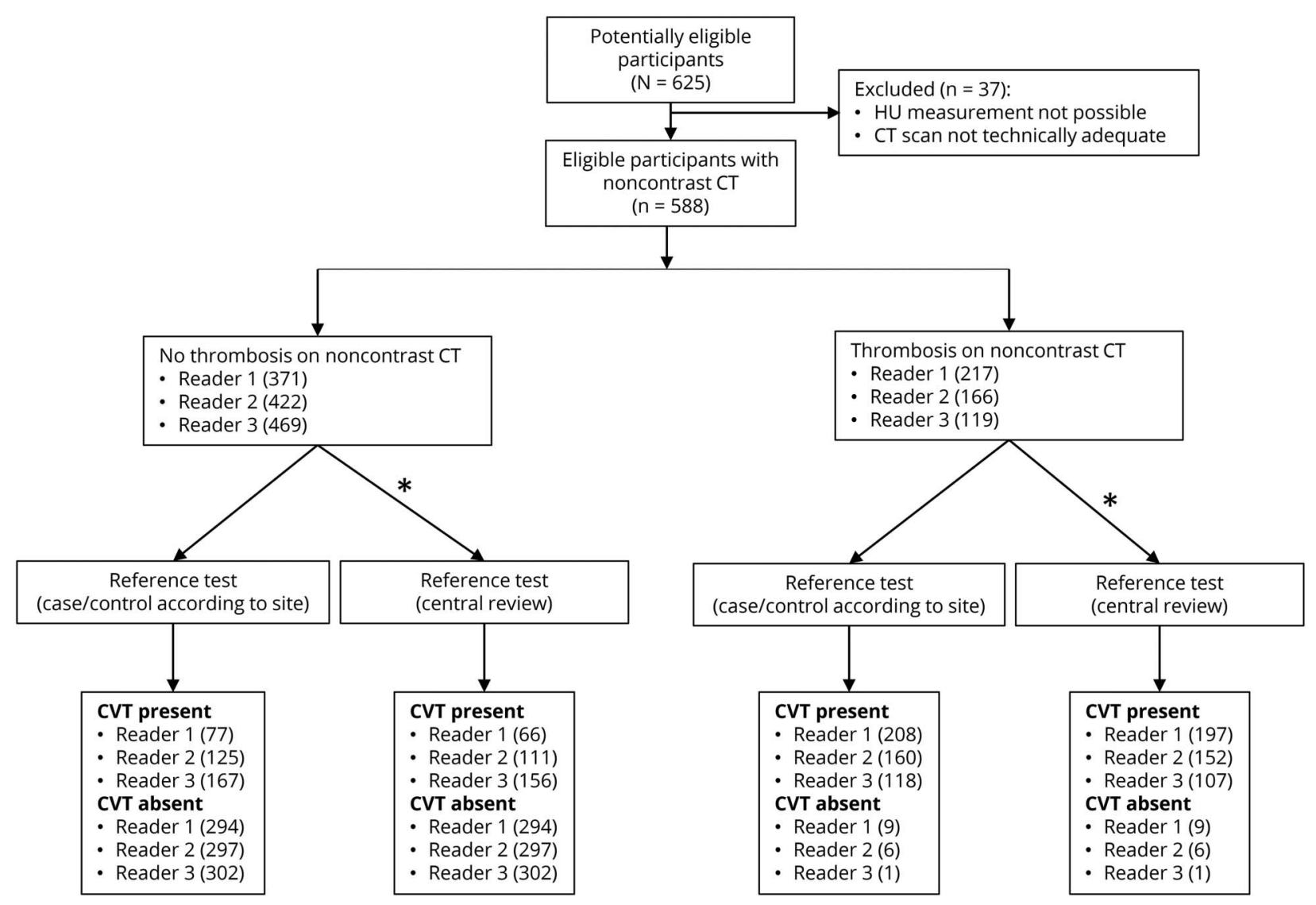

*No confirmatory images available $(n=14)$. No cerebral venous thrombosis $(C V T)$ on central review $(n=8)$. HU = Hounsfield units.

was 1.52 , and for ratio of affected/unaffected was 1.3 , as suggested in prior studies. ${ }^{11,13}$ An area under the curvereceiver operating characteristic (AUC-ROC) analysis was also performed to identify more appropriate cutoffs.

Venous thromboses were divided into thrombosis affecting the superficial venous system (cortical veins, superior sagittal sinus, transverse and sigmoid sinus) and thrombosis affecting the deep venous system (straight sinus, internal cerebral veins, vein of Galen, vein of Rosenthal). ${ }^{17}$

We used 2 reference standards. The first reference standard was the local site investigator's case or control status, which was based on all the information available including the index test. The second reference test was 1 experienced reader (V.T., vascular neurologist with more than 15 years' experience) who reviewed the MRI or CTV or digital subtraction angiography (DSA) of all CVT cases to confirm the diagnosis. All available MRI sequences were used to make a diagnosis of CVT and to rule out congenital hypoplasia. These variably included the following sequences: T1, T2, fluid-attenuated inversion recovery, gradient recalled echo or susceptibilityweighted imaging, diffusion-weighted images, postcontrast $\mathrm{T} 1$, and magnetic resonance venograms. On DSA, the venous phase was used to identify thrombosis. In cases where this reader could not confirm the diagnosis, a second experienced neuroradiologist (H.A., with more than 5 years of experience) confirmed presence or absence of CVT.

\section{Standard protocol approvals, registrations, and patient consents}

Specific approval of the project by an ethics committee (Leuven, Austria) or a waiver due to the anonymized, retrospective data and imaging collection (Amsterdam, Nîmes, Mexico City, Essen, Brescia, Seville, Barcelona, Helsinki) were obtained by each participating site, according to local regulations.

\section{Statistical analysis}

We estimated a sample size of 300 patients and 300 controls in order to demonstrate a sensitivity of $93 \%$ and a specificity of $93 \%$ with the lower 95\% confidence limit in 2 epochs (within 48 hours, between 3 days and 2 weeks after symptom onset) with a $50 \%$ prevalence of CVT, given the 1:1 case control ratio. ${ }^{18}$ Intraclass correlation coefficients (ICCs) and corresponding 95\% confidence intervals (CIs) were calculated based on a mean rating $(k=3)$, absolute agreement, 2 -way mixedeffects model. The incremental value of CT attenuation measures relative to visual analysis of direct and indirect signs was measured using the incrisk procedure. We calculated the 
incremental change in AUC-ROC and the continuous net reclassification index with corresponding $95 \%$ CIs of a model incorporating nondichotomized $\mathrm{CT}$ attenuation measures with the baseline assessment of the CT. ${ }^{19}$ Because a sensitive test for CVT would be most desirable, we additionally tested whether a model incorporating the imaging marker would increase discrimination, accepting a false-positive rate of $20 \%$. For this analysis, we used the roccurve procedure. ${ }^{20}$ Calibration was assessed by comparing the Bayesian Information Criterion (BIC) of a model with and without the imaging biomarker, with values above 5 indicating strong preference for the model that includes the imaging marker. All analyses were performed in Stata 15.0. We performed prespecified analyses according to time since symptom onset, dichotomized between 0 and 48 hours, and 48 hours to 2 weeks.

\section{Data availability policy}

The anonymized data for this study will be shared by request from any qualified investigator to the corresponding author.

\section{Results}

\section{Patients}

We obtained noncontrast CT scans from 625 patients, collected between 2001 and 2015. We excluded 37 patients in whom HU measurements could not be reliably measured. This left 588 patients for analysis (figure 2). The demographic features and clinical characteristics of the included patients are shown in table 1 . Cases $(n=285)$ were well-matched to controls $(n=303)$ in terms of age; however, there were more male controls.

Figure 2 Hounsfield unit (HU) measurement and representative imaging

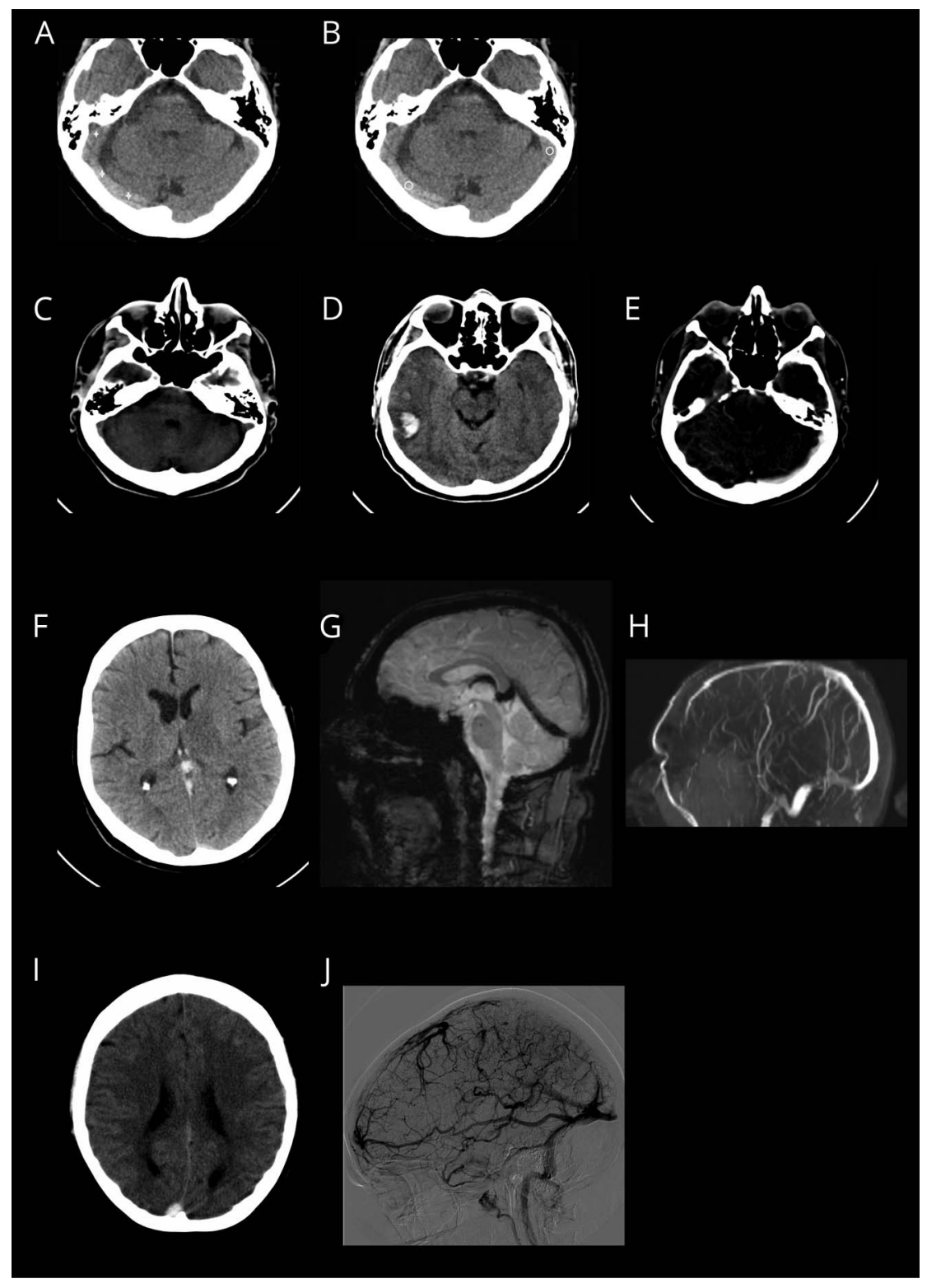

(A) Imaging assessment of patient with suspected right transverse sinus thrombosis. Crosshairs represent location of measurement of $\mathrm{HU}$ at 3 places within dense sinus. The HU values were 67,72 , and 69. (B) Comparison of average HU in hyperdense right transverse sinus and left sigmoid sinus. The average $\mathrm{HU}$ within the region of interest was 71 and 47 in the sigmoid sinus. (C, D, F, I) Representative noncontrast $C T$ and $(E, G, H, J)$ confirmation images. (C) Normal-appearing right sigmoid and transverse sinus. (D) Hemorrhagic infarct in right temporal lobe of same patient. (E) Absence of contrast filling on $\mathrm{CT}$ venogram in $\mathrm{R}$ transverse sinus (compare with normal filling pattern on $\mathrm{L}$ transverse sinus). (F) Hyperdensity on noncontrast CT in straight sinus, vein of Galen, and internal cerebral veins (average HU 71) and slight parenchymal hypodensity in $L$ thalamus and lentiform nucleus. (G) Gradient recalled echo imaging shows hypointensity in deep cerebral venous system. $(\mathrm{H})$ Absence of filling on time of flight magnetic resonance venography. (I) Hyperdensity in superior sagittal sinus (HU 79). (J) Intra-arterial digital subtraction angiography demonstrates absence of filling in superior sagittal sinus. 
Table 1 Demographic characteristics, risk factors, and associated diseases

\begin{tabular}{llll}
\hline & $\begin{array}{l}\text { Cases } \\
(\mathbf{n}=\mathbf{2 8 5})\end{array}$ & $\begin{array}{l}\text { Controls } \\
(\mathbf{n}=\mathbf{3 0 3})\end{array}$ & $\begin{array}{l}\boldsymbol{p} \\
\text { Value }\end{array}$ \\
\hline Age, y, mean (SD) & $42.4(15.6)$ & $44.5(17.2)$ & 0.12 \\
\hline Female & $214(75)$ & $198(65)$ & 0.01 \\
\hline $\begin{array}{l}\text { Time between index and } \\
\text { reference test, d, median (IQR) }\end{array}$ & $0(0-1)$ & $0(0-1)$ & 0.31 \\
\hline $\begin{array}{l}\text { Index test within 48 hours of } \\
\text { symptom onset }\end{array}$ & $123(43)$ & $210(69)$ & 0.001 \\
\hline $\begin{array}{l}\text { Thrombophilia } \\
\text { a }\end{array}$ & $50(20)$ & & \\
\hline $\begin{array}{l}\text { Contraception/hormonal } \\
\text { replacement therapy }\end{array}$ & $109(51)$ & & \\
\hline $\begin{array}{l}\text { Medication (steroids, } \\
\text { L-asparaginase therapy, } \\
\text { methotrexate) }\end{array}$ & $24(8)$ & & \\
\hline $\begin{array}{l}\text { Trauma/surgery/lumbar } \\
\text { puncture }\end{array}$ & $17(6)$ & & \\
\hline $\begin{array}{l}\text { Local or systemic infection } \\
\text { Cancer/hematologic disease }\end{array}$ & $24(8)$ & & \\
\hline $\begin{array}{l}\text { Inflammatory diseases } \\
\text { Miscellaneous }\end{array}$ & $15(20)$ & & \\
\hline $\begin{array}{l}\text { No associated } \\
\text { condition/risk factor }\end{array}$ & $13(5)$ & & \\
\hline $\begin{array}{l}\text { Pregnancy/puerperium } \\
\text { (5) }\end{array}$ & $12(4)$ & & \\
\hline & $22(8)$ & & \\
\hline
\end{tabular}

Abbreviation: $I Q R$ = interquartile range.

Values are $\mathrm{n}(\%)$ unless otherwise indicated.

a Missing/not tested in 37.

${ }^{\mathrm{b}}$ In women.

\section{Cases}

There were 215 patients (75.4\%) with superficial CVT (isolated superior sagittal sinus, $\mathrm{n}=26$, isolated cortical vein, $\mathrm{n}=10$, isolated lateral sinus, i.e., transverse sinus, sigmoid sinus, $\mathrm{n}=102$, and combinations of these, $\mathrm{n}=77)$ and $8(2.8 \%)$ with deep CVT (sinus rectus, $n=7$, vein of Galen and internal cerebral vein, $n=$ 1). Involvement of both deep and superficial venous systems was present in 40 patients (14.1\%). Examples of scans are shown in figure 2. The location of the venous thrombosis was not available in 22 patients (7.7\%). In 14 patients, we did not have access to the confirmatory images and in 8 patients venous thrombosis could not be confirmed by the central image readers on the provided images. There were 123 cases and 210 controls who had noncontrast CT within 48 hours of initial symptoms and 162 cases and 93 controls scanned between 48 hours and 2 weeks. Combinations of headache, focal neurologic findings, seizures, and altered mental states were found in $158(55 \%)$ patients. Less frequent presentations included isolated headache $(\mathrm{n}=89,31 \%)$, isolated focal neurologic deficits $(\mathrm{n}=17,6 \%)$, isolated seizures $(\mathrm{n}=15,5 \%)$, and isolated altered mental state $(n=6,2 \%)$. The index test and the reference test were mostly performed on the same day (median delay, 0 days, interquartile range $0-1$ day). The reference tests used to make a diagnosis of CVT were MRI based in 118, CTV in 114, IADSA in 5, and combinations in 48 cases. The average hematocrit value was $38.8 \%$ (SD 5.9\%). Hematocrit values were missing in 19 cases.

\section{Controls}

The most common diagnoses in the control group were primary $(\mathrm{n}=66)$ or secondary headache $(\mathrm{n}=23)$ syndromes, ischemic stroke/TIA $(\mathrm{n}=102)$, or intracerebral hemorrhage $(\mathrm{n}=27)$. Brain tumors $(\mathrm{n}=15)$, psychiatric/no organic syndrome $(\mathrm{n}=16)$, CNS infections $(\mathrm{n}=16)$, optic neuropathies $(\mathrm{n}=4)$, vascular malformations or dissections of cervicocephalic arteries $(\mathrm{n}=8)$, and seizures $(\mathrm{n}=11)$ were less frequent. Other miscellaneous causes were present in 4 controls. The index test and the reference test were mostly performed on the same day for controls (median delay, 0 days, interquartile range $0-1$ days). The reference tests used to exclude a diagnosis of CVT were MRI in 125, CTV in 142, IADSA in 5, and combinations of these tests in 30. In one patient, no additional imaging was performed, but CSF analysis confirmed the presence of a viral meningitis. The average hematocrit value in controls was $40.2 \%$ (SD 5.3\%). Hematocrit values were missing in 10 controls. The hematocrit in cases was lower than in controls (mean difference 1.4 [95\% CI 0.5-2.4], $p=0.003$ ).

\section{Imaging results: Direct and indirect signs of CVT}

The kappa value for diagnosis of CVT based on qualitative assessment of the CT was 0.55 (95\% CI 0.49-0.60). Table 2 summarizes the diagnostic accuracy of direct and indirect signs of CVT on noncontrast CT. The sensitivity was low to moderate $(41 \%-73 \%)$. The specificity was very high (97\%-100\%). The positive predictive value and likelihood ratios were very high. The diagnostic accuracy was similar when only patients with confirmed CVT were included or when patients were scanned early or late after symptom onset.

\section{Imaging results: Attenuation ratios and prespecified thresholds}

The reliability of the 3 readers with respect to attenuation markers was moderate to very high, with an intraclass correlation coefficient of 0.87 (95\% CI 0.85-0.89) for HU measurement, 0.92 (0.9-0.93) for $\mathrm{H}: \mathrm{H}$ ratio, and 0.54 (95\% CI 0.46-0.60) for ratio of affected/unaffected. HU in cases were higher compared to controls for the 3 readers with an average difference of $11 \mathrm{HU}$ (95\% CI 9-12). This difference was 9 (95\% CI 7-11) in the acute vs 12 (95\% CI 9-14) in the subacute phase. There was a modest correlation between $\mathrm{HU}$ and hematocrit in both cases and controls. In controls, the correlation coefficient was 0.253 ( $p$ $<0.00001)$ and in cases $0.156(p=0.01)$. The predefined cutoffs of $\mathrm{HU}>62, \mathrm{H}: \mathrm{H}$ ratio $>1.52$, and affected/unaffected ratio 1.3 had moderate sensitivity and specificity (table 3 ). The diagnostic accuracy was similar when only patients with confirmed CVT were included or when patients were scanned early or late after symptom onset. Of the 3 measures, the affected/unaffected ratio had the highest specificity. The diagnostic accuracy was similar 
Table 2 Diagnostic accuracy of visual assessment of noncontrast CT based on direct and indirect signs

\begin{tabular}{|c|c|c|c|c|c|c|}
\hline & $\begin{array}{l}\text { Sensitivity } \\
(95 \% \mathrm{CI})\end{array}$ & $\begin{array}{l}\text { Specificity } \\
(95 \% \mathrm{CI})\end{array}$ & $\begin{array}{l}\text { Positive } \\
\text { predictive } \\
\text { value }(95 \% \mathrm{CI})\end{array}$ & $\begin{array}{l}\text { Negative } \\
\text { predictive } \\
\text { value }(95 \% \mathrm{Cl})\end{array}$ & $\begin{array}{l}\text { Likelihood ratio } \\
(+)(95 \% \mathrm{CI})\end{array}$ & $\begin{array}{l}\text { Likelihood } \\
\text { ratio } \\
(-)(95 \% \mathrm{Cl})\end{array}$ \\
\hline \multicolumn{7}{|c|}{$\begin{array}{l}\text { Visual assessment: total } \\
\text { group } \\
(n=588)\end{array}$} \\
\hline Reader 1 & $\begin{array}{l}0.73 \\
(0.70-0.75)\end{array}$ & $\begin{array}{l}0.97 \\
(0.95-0.99)\end{array}$ & $0.96(0.93-0.98)$ & $0.79(0.77-0.81)$ & $24.57(13.03-49.94)$ & $\begin{array}{l}0.28 \\
(0.26-0.31)\end{array}$ \\
\hline Reader 2 & $\begin{array}{l}0.56 \\
(0.55-0.59)\end{array}$ & $\begin{array}{l}0.98 \\
(0.96-0.99)\end{array}$ & $0.96(0.92-0.99)$ & $0.70(0.69-0.71)$ & $28.35(12.68-70.12)$ & $\begin{array}{l}0.45 \\
(0.43-0.48)\end{array}$ \\
\hline Reader 3 & $\begin{array}{l}0.41 \\
(0.40-0.42)\end{array}$ & $\begin{array}{l}1.00 \\
(0.98-1.00)\end{array}$ & $0.99(0.95-1.00)$ & $0.64(0.63-0.65)$ & $\begin{array}{l}125.45 \\
(19.71-2,420.78)\end{array}$ & $\begin{array}{l}0.59 \\
(0.58-0.62)\end{array}$ \\
\hline \multicolumn{7}{|c|}{ Visual assessment: acute } \\
\hline Reader 1 & $\begin{array}{l}0.72 \\
(0.64-0.80)\end{array}$ & $\begin{array}{l}0.98 \\
(0.95-1.0)\end{array}$ & $0.96(0.89-0.99)$ & $0.86(0.81-0.90)$ & $38(14.3-101)$ & $\begin{array}{l}0.28 \\
(0.21-0.38)\end{array}$ \\
\hline Reader 2 & $\begin{array}{l}0.56 \\
(0.47-0.65)\end{array}$ & $\begin{array}{l}0.98 \\
(0.95-1.0)\end{array}$ & $0.95(0.87-0.99)$ & $0.79(0.74-0.84)$ & $30(11-78.7)$ & $\begin{array}{l}0.45 \\
(0.37-0.55)\end{array}$ \\
\hline Reader 3 & $\begin{array}{l}0.46 \\
(0.37-0.56)\end{array}$ & $\begin{array}{l}1.00 \\
(0.97-1.00)\end{array}$ & $0.98(0.91-1.00)$ & $0.76(0.71-0.81)$ & 181 (30.9-Inf) & $\begin{array}{l}0.54 \\
(0.46-0.64)\end{array}$ \\
\hline \multicolumn{7}{|c|}{ Visual assessment: subacute } \\
\hline Reader 1 & $\begin{array}{l}0.74 \\
(0.66-0.80)\end{array}$ & $\begin{array}{l}0.95 \\
(0.88-0.98)\end{array}$ & $0.96(0.91-0.99)$ & $0.67(0.58-0.75)$ & $13.7(5.8-32.2)$ & $\begin{array}{l}0.28 \\
(0.22-0.36)\end{array}$ \\
\hline Reader 2 & $\begin{array}{l}0.56 \\
(0.48-0.64)\end{array}$ & $\begin{array}{l}0.98 \\
(0.92-1.0)\end{array}$ & $0.98(0.92-1.0)$ & $0.56(0.48-0.64)$ & $26.1(6.6-104)$ & $\begin{array}{l}0.45 \\
(0.38-0.54)\end{array}$ \\
\hline Reader 3 & $\begin{array}{l}0.38 \\
(0.30-0.46)\end{array}$ & $\begin{array}{l}1.00 \\
(0.96-1.00)\end{array}$ & $1(0.94-1.00)$ & $0.48(0.41-0.55)$ & $71(4.4-1,134)$ & $\begin{array}{l}0.62 \\
(0.55-0.70)\end{array}$ \\
\hline \multicolumn{7}{|c|}{$\begin{array}{l}\text { Visual assessment: central } \\
\text { review }\end{array}$} \\
\hline Reader 1 & $\begin{array}{l}0.75 \\
(0.69-0.80)\end{array}$ & $\begin{array}{l}0.97 \\
(0.94-0.99)\end{array}$ & $0.96(0.92-0.98)$ & $0.82(0.77-0.86)$ & $25.2(13.2-48.2)$ & $\begin{array}{l}0.26 \\
(0.21-0.32)\end{array}$ \\
\hline Reader 2 & $\begin{array}{l}0.58 \\
(0.52-0.64)\end{array}$ & $\begin{array}{l}0.98 \\
(0.96-0.99)\end{array}$ & $0.96(0.92-0.99)$ & $0.73(0.68-0.77)$ & $29.2(13.1-64.9)$ & $\begin{array}{l}0.43 \\
(0.37-0.50)\end{array}$ \\
\hline Reader 3 & $\begin{array}{l}0.41 \\
(0.35-0.47)\end{array}$ & $\begin{array}{l}1.00 \\
(0.98-1.00)\end{array}$ & $0.99(0.95-1.00)$ & $0.66(0.61-0.7)$ & 123 (17.3-877) & $\begin{array}{l}0.60 \\
(0.54-0.66)\end{array}$ \\
\hline
\end{tabular}

Abbreviation: $\mathrm{Cl}$ = confidence interval

when images were centrally adjudicated or when patients were scanned early or late after symptom onset.

\section{Imaging results: $\mathrm{ROC}$ analysis}

Figure 3 shows the ROC curves of the different attenuation markers. The highest AUC was obtained with the affected/ unaffected ratio. Discrimination of the 3 attenuation markers was similar when images were centrally adjudicated or when patients were scanned early or late after symptom onset (table 4).

\section{Incremental results of visual and attenuation measures for diagnosis of CVT}

Compared to visual assessment alone, increases in discrimination were found with the 3 imaging markers (table 5), as assessed by significant AUC increases and continuous net reclassification index changes for almost all of the assessments and readers. The strongest improvement in discrimination was found with the affected/unaffected ratio, which significantly increased discrimination for the 3 readers.

Calibration was also improved for most readers, as shown with the increases in BIC with a value of more than 5 for almost all of the assessments by the 3 readers.

The sensitivity at a false-positive threshold of 0.2 was 0.76 (0.70-0.81), higher than the sensitivity of the visual assessment in reader 2 and reader 3 , but not reader 1 (figure 3 ).

\section{Discussion}

In this large, international, multicenter collaboration with multiple raters, we found that visual analysis of plain $\mathrm{CT}$ was 
Table 3 Diagnostic accuracy of imaging markers with prespecified cutoffs

\begin{tabular}{|c|c|c|c|c|c|c|}
\hline & $\begin{array}{l}\text { Sensitivity } \\
(95 \% \mathrm{Cl})\end{array}$ & $\begin{array}{l}\text { Specificity } \\
(95 \% \mathrm{Cl})\end{array}$ & $\begin{array}{l}\text { Positive } \\
\text { predictive } \\
\text { value }(95 \% \mathrm{Cl})\end{array}$ & $\begin{array}{l}\text { Negative } \\
\text { predictive } \\
\text { value }(95 \% \mathrm{Cl})\end{array}$ & $\begin{array}{l}\text { Likelihood } \\
\text { ratio } \\
(+)(95 \% \mathrm{Cl})\end{array}$ & $\begin{array}{l}\text { Likelihood } \\
\text { ratio } \\
(-)(95 \% \mathrm{Cl})\end{array}$ \\
\hline \multicolumn{7}{|l|}{$\begin{array}{l}\text { Prespecified cutoffs } \\
(n=588)\end{array}$} \\
\hline $\mathrm{HU}>62$ & $0.67(0.62-0.73)$ & $0.81(0.76-0.85)$ & $0.77(0.71-0.82)$ & $0.73(0.68-0.77)$ & $3.6(2.8-4.6)$ & $0.4(0.34-0.48)$ \\
\hline $\mathrm{H}: \mathrm{H}$ ratio $>1.52$ & $0.74(0.68-0.79)$ & $0.7(0.64-0.75)$ & $0.70(0.64-0.75)$ & $0.74(0.68-0.79)$ & $2.44(2.02-2.92)$ & $0.38(0.31-0.47)$ \\
\hline Affected/unaffected $>1.3$ & $0.63(0.57-0.68)$ & $0.90(0.87-0.94)$ & $0.86(0.81-0.90)$ & $0.72(0.67-0.76)$ & $6.53(4.56-9.33)$ & $0.42(0.36-0.48)$ \\
\hline \multicolumn{7}{|l|}{ Predefined cutoffs: acute } \\
\hline $\mathrm{HU}>62$ & $0.60(0.51-0.69)$ & $0.78(0.72-0.84)$ & $0.62(0.52-0.70)$ & $0.77(0.71-0.83)$ & $2.8(2.1-3.7)$ & $0.5(0.41-0.64)$ \\
\hline $\mathrm{H}: \mathrm{H}$ ratio $>1.52$ & $0.65(0.56-0.74)$ & $0.74(0.68-0.80)$ & $0.59(0.50-0.68)$ & $0.79(0.72-0.84)$ & $2.5(1.9-3.3)$ & $0.47(0.36-0.61)$ \\
\hline $\begin{array}{l}\text { Affected/unaffected } \\
>1.3\end{array}$ & $0.61(0.52-0.70)$ & $0.90(0.85-0.94)$ & $0.78(0.69-0.86)$ & $0.80(0.74-0.85)$ & $6.1(4.0-9.4)$ & $0.43(0.35-0.54)$ \\
\hline \multicolumn{7}{|l|}{$\begin{array}{l}\text { Predefined cutoffs: } \\
\text { subacute }\end{array}$} \\
\hline $\mathrm{HU}>62$ & $0.73(0.65-0.80)$ & $0.88(0.80-0.94)$ & $0.92(0.85-0.96)$ & $0.65(0.56-0.73)$ & $6.2(3.5-10.8)$ & $0.31(0.24-0.40)$ \\
\hline $\mathrm{H}: \mathrm{H}$ ratio $>1.52$ & $0.77(0.70-0.84)$ & $0.67(0.56-0.76)$ & $0.80(0.72-0.86)$ & $0.63(0.52-0.73)$ & $2.3(1.7-3.2)$ & $0.34(0.25-0.48)$ \\
\hline $\begin{array}{l}\text { Affected/unaffected > } \\
1.3\end{array}$ & $0.64(0.56-0.71)$ & $0.91(0.84-0.96)$ & $0.93(0.86-0.97)$ & $0.59(0.51-0.67)$ & $7.4(3.8-14.5)$ & $0.4(0.32-0.49)$ \\
\hline \multicolumn{7}{|l|}{$\begin{array}{l}\text { Predefined cutoffs: } \\
\text { central } \\
\text { review }(n=566)\end{array}$} \\
\hline $\mathrm{HU}>62$ & $0.68(0.62-0.74)$ & $0.81(0.76-0.85)$ & $0.76(0.70-0.81)$ & $0.75(0.70-0.79)$ & $3.6(2.8-4.6)$ & $0.4(0.33-0.47)$ \\
\hline $\mathrm{H}: \mathrm{H}$ ratio $>1.52$ & $0.73(0.67-0.78)$ & $0.72(0.67-0.77)$ & $0.68(0.62-0.74)$ & $0.76(0.70-0.81)$ & $2.6(2.1-3.2)$ & $0.38(0.31-0.47)$ \\
\hline Affected/unaffected $>1.3$ & $0.63(0.57-0.69)$ & $0.90(0.87-0.94)$ & $0.85(0.79-0.90)$ & $0.74(0.69-0.78)$ & $6.6(4.6-9.4)$ & $0.41(0.35-0.48)$ \\
\hline
\end{tabular}

Abbreviations: $\mathrm{H}: \mathrm{H}=$ Hounsfield unit/hematocrit; $\mathrm{HU}=$ Hounsfield unit.

highly specific but only moderately sensitive of CVT. Our prespecified semiquantitative measure thresholds did not achieve the prespecified sensitivity and specificity targets. When analyzed over the entire range, these markers provided improved discrimination between cases and controls, but were insufficient to rule out CVT.

The marker with the highest discrimination was the ratio of $\mathrm{HU}$ in the presumably affected vs an unaffected venous sinus. This marker does not require knowledge of the hematocrit and is therefore available in all technically satisfactory scans. The marker may be difficult to obtain reliably in situations where bilateral thrombosis occurs or where only the superior sagittal sinus is involved. Previous studies had suggested that attenuation markers increased diagnostic accuracy substantially. ${ }^{9-13}$ However, these studies were small, retrospective, and performed on a limited number of CT scanners. Moreover, the controls in these studies were not always controls at risk of CVT, which may inflate diagnostic accuracy. ${ }^{21}$ In contrast to previous studies, we tested the incremental value of a quantitative assessment of hypoattenuation above and beyond the combination of direct and indirect signs. ${ }^{22}$ These signs proved highly specific but were only moderately sensitive. Adding the ratio of $\mathrm{HU}$ in the presumably affected sinus vs the unaffected sinus increased sensitivity but, even if accepting a false-positive rate of $20 \%$, this imaging marker did not reach sensitivities high enough to rule out CVT confidently. This reaffirms current guidelines that require additional imaging with CTV or MRV when a CVT is suspected. ${ }^{7,8}$

The interrater reliability of $\mathrm{CT}$ visual assessment was only moderate, with the 3 readers achieving high specificity but sensitivities ranging only from $41 \%$ to $71 \%$. This may reflect the various backgrounds of our readers or different thresholds to ascribe imaging features to CVT.

The benefits of attenuation measurement may be highest in readers who have less experience or a higher threshold before considering CVT. Among the 3 readers, the ICCs were highest for the $\mathrm{HU}$ and the $\mathrm{H}: \mathrm{H}$ ratio measurement, whereas the ratio of affected or unaffected had only moderate agreement. Although this marker proved the most promising, standardization of measurement will need to occur. 


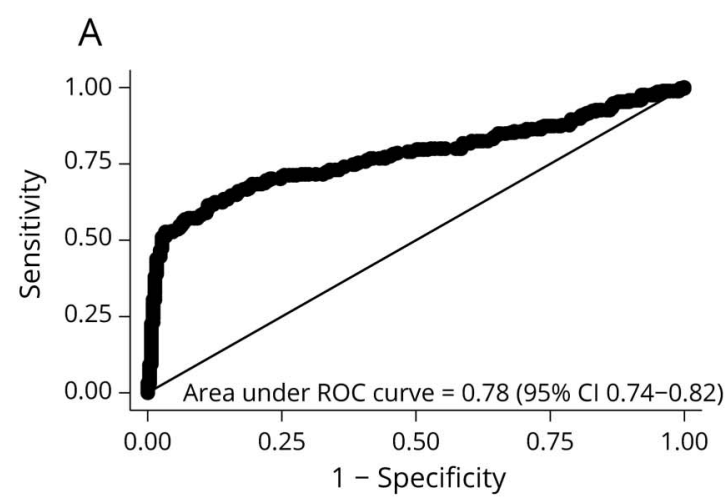

C

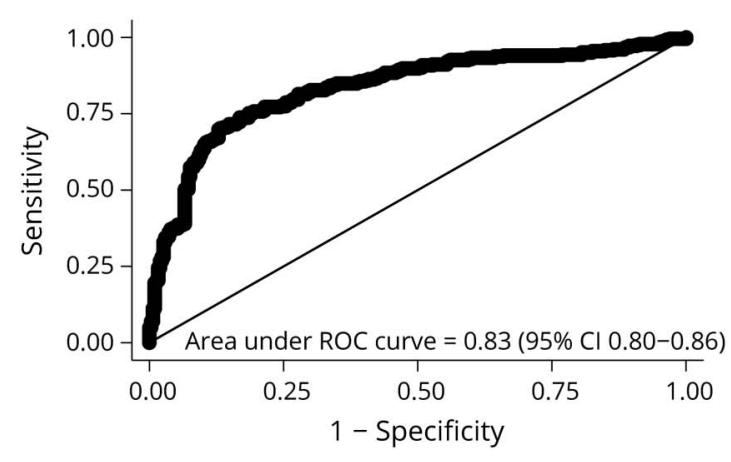

B

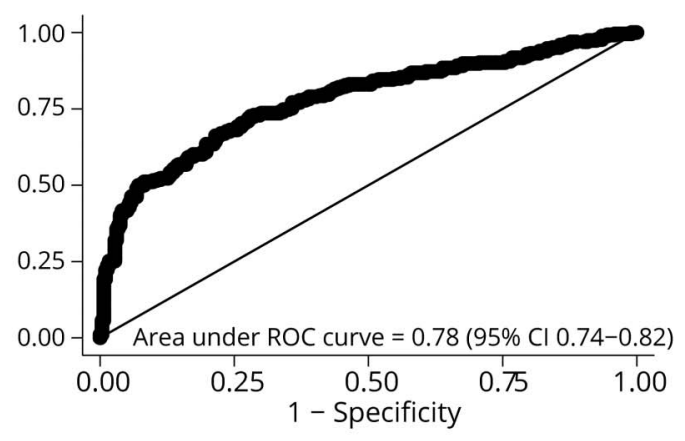

D

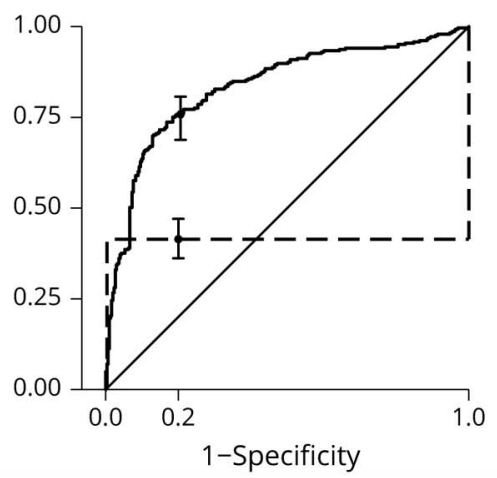

ROC curves for (A) Hounsfield unit (HU) measurements, (B) HU/hematocrit ratio, and (C) ratio of HU measurement in affected vs unaffected sinus. (D) The sensitivity at a false-positive rate of $20 \%$ is shown in for reader 3 , who has the lowest sensitivity of the 3 readers (shown as dashed lines). $\mathrm{Cl}=$ confidence interval.

Surprisingly, we were not able to show a difference in the diagnostic accuracy of noncontrast CT in patients who were scanned early or late after onset of symptoms. Previous studies have shown that acute clots are denser than subacute clots. ${ }^{23,24}$ In our study, the difference in HU between acute cases and controls and subacute cases and controls increased, rather than decreased.

Table 4 Area under the curve (AUC)-receiver operating characteristic analysis results $(95 \% \mathrm{CI})$

\begin{tabular}{llll}
\hline & HU & H:H ratio & $\begin{array}{l}\text { Ratio affected/ } \\
\text { unaffected }\end{array}$ \\
\hline All patients & $0.78(0.74-0.82)$ & $0.78(0.74-0.82)$ & $0.83(0.80-0.87)$ \\
\hline Acute & $0.74(0.68-0.8)$ & $0.75(0.69-0.82)$ & $0.84(0.80-0.89)$ \\
\hline Subacute & $0.81(0.76-0.86)$ & $0.79(0.73-0.85)$ & $0.83(0.78-0.88)$ \\
\hline
\end{tabular}

\section{Central review}

( $n=566$ )

\begin{tabular}{llll}
\hline Total group & $0.78(0.74-0.82)$ & $0.78(0.74-0.82)$ & $0.84(0.81-0.88)$ \\
\hline Acute & $0.74(0.67-0.80)$ & $0.75(0.69-0.81)$ & $0.85(0.80-0.89)$ \\
\hline Subacute & $0.82(0.77-0.88)$ & $0.80(0.74-0.86)$ & $0.85(0.80-0.90)$
\end{tabular}

Abbreviations: $\mathrm{Cl}=$ confidence interval; $\mathrm{H}: \mathrm{H}=$ Hounsfield unit/hematocrit; $\mathrm{HU}=$ Hounsfield unit.
It is often difficult to determine the true onset of symptoms in patients with CVT as initial findings may be nonspecific and there may be a recall bias. There may also be a delay between the onset of venous thrombosis and the development of symptoms. Indeed, even entirely asymptomatic CVT have been reported. ${ }^{25}$

The strengths of this study include the large sample size, the multicenter nature, and use of blinded raters who had varying degrees of expertise, which together reflect a real-world setting where the scans are often initially reviewed by less experienced raters. This study also has limitations. We performed a retrospective study because a prospective study of CVT would be difficult due to the rarity of CVT. Due to the retrospective nature we also cannot guarantee that consecutive patients were enrolled in the study and therefore selection bias may have occurred. We did not collect information about the severity of the disease, other than the clinical syndromes. The raters knew that half of the patients had a CVT, a frequency that does not correspond to the true frequency of CVT among patients presenting with headache, focal neurologic findings, seizures, altered mental state, or combinations thereof. The diagnostic accuracy is probably lower in a real-world setting, where only $1 \%-2 \%$ of scanned patients have a CVT. The HU measurement may have been biased if parenchymal lesions were present that were highly suggestive of CVT, as the reviewers were 
Table 5 Discrimination and calibration of imaging markers in addition to visual assessment of noncontrast CT $(n=588)$

\begin{tabular}{|c|c|c|c|c|c|c|c|}
\hline & $\begin{array}{l}\text { AUC model } \\
\text { with marker - } \\
\text { model without } \\
\text { marker }(95 \% \mathrm{CI})\end{array}$ & $\begin{array}{l}\text { Continuous } \\
\text { NRI }(95 \% \mathrm{Cl})\end{array}$ & $\begin{array}{l}\text { Continuous } \\
\text { event NRI } \\
(95 \% \mathrm{Cl})\end{array}$ & $\begin{array}{l}\text { Continuous } \\
\text { nonevent NRI } \\
(95 \% \mathrm{Cl})\end{array}$ & $\begin{array}{l}\text { BIC base } \\
\text { model } \\
\text { without } \\
\text { marker }\end{array}$ & $\begin{array}{l}\text { BIC } \\
\text { with } \\
\text { base } \\
\text { model } \\
\text { with } \\
\text { marker }\end{array}$ & $\begin{array}{l}\text { BIC } \\
\text { change }\end{array}$ \\
\hline \multicolumn{8}{|l|}{$\begin{array}{l}\text { Average } \\
\text { HU }\end{array}$} \\
\hline Reader 1 & 0.02 (-0.02 to 0.06$)$ & $-0.013(-0.183$ to 0.352$)$ & $-0.102(-0.125$ to 0.171$)$ & $0.089(-0.142$ to 0.256$)$ & -354 & -348 & 6 \\
\hline Reader 2 & 0.10 (0.06 to 0.13$)$ & 0.311 (0.060 to 0.573$)$ & 0.235 (0.100 to 0.369$)$ & $0.076(-0.059$ to 0.219$)$ & -243 & -252 & 8 \\
\hline Reader 3 & 0.18 (0.14 to 0.22$)$ & 0.71 (0.52 to 1.07$)$ & 0.333 (0.230 to 0.617$)$ & 0.380 ( 0.254 to 0.499$)$ & -186 & -250 & 64 \\
\hline \multicolumn{8}{|l|}{ H:H ratio } \\
\hline Reader 1 & 0.05 (0.03 to 0.08$)$ & $0.218(-0.045$ to 0.424$)$ & $0.030(-0.106$ to 0.163$)$ & 0.188 (0.008 to 0.317$)$ & -341 & -341 & 0 \\
\hline Reader 2 & 0.12 (0.08 to 0.15$)$ & 0.455 (0.280 to 0.655$)$ & 0.158 (0.041 to 0.289$)$ & $0.297(0.202$ to 0.399$)$ & -230 & -257 & 27 \\
\hline Reader 3 & 0.19 (0.15 to 0.23$)$ & 0.737 (0.563 to 1.130$)$ & 0.331 (0.214 to 0.662$)$ & $0.406(0.294$ to 0.520$)$ & -171 & -237 & 66 \\
\hline \multicolumn{8}{|l|}{$\begin{array}{l}\text { Ratio } \\
\text { affected/ } \\
\text { unaffected }\end{array}$} \\
\hline Reader 1 & 0.09 (0.07 to 0.12$)$ & 0.655 (0.429 to 0.820$)$ & $0.137(-0.041$ to 0.252$)$ & 0.518 ( 0.426 to 0.611$)$ & -354 & -375 & 21 \\
\hline Reader 2 & 0.18 (0.15 to 0.21$)$ & 0.853 (0.655 to 1.012$)$ & 0.242 (0.089 to 0.358$)$ & 0.611 (0.521 to 0.692$)$ & -244 & -305 & 61 \\
\hline Reader 3 & 0.24 (0.20 to 0.28$)$ & 1.045 (0.907 to 1.392$)$ & 0.368 (0.259 to 0.662$)$ & 0.677 (0.613 to 0.752$)$ & -186 & -302 & 116 \\
\hline
\end{tabular}

Abbreviations: $\mathrm{AUC}=$ area under the curve; $\mathrm{BIC}=$ Bayesian Information Criterion; $\mathrm{Cl}=$ confidence interval; $\mathrm{H}: \mathrm{H}=\mathrm{Hounsfield}$ unit/hematocrit ratio; $\mathrm{HU}=$ Hounsfield units; $\mathrm{NRI}=$ net reclassification index.

not blinded to these signs. Scans were obtained over a period of 15 years, and the technology and acquisition measures have changed over this time period. Thin-slice CT and multiplanar reconstruction were often not available. We did not collect details on the vendors, software version, or scan detectors. Slice thickness was variable. A limitation of all attenuation measurements are variations of HU measurements across the length of the sinuses and partial volume artefacts because of the proximity of bones and veins. We may have missed involvement of cortical veins if limited sequences or only CTV were available. No formal assessment was made of the asymmetry of the transverse sinus. There was a slight delay between acquisition of the noncontrast $\mathrm{CT}$ scans and the confirmatory images when a different modality was used, and image characteristics may have potentially changed in this interval. It is unlikely that this slight delay affects our conclusions. In the controls, the presence of pathologies such as brain tumors or arteriovenous malformations may have slightly influenced $\mathrm{HU}$ values, but there were only a few of these patients in the control group. Information on D-dimer testing was not available and adding this information could have further strengthened diagnostic accuracy. ${ }^{26,27}$

\section{Study funding}

The Florey Institute of Neuroscience and Mental Health acknowledges support from the Victorian Government and in particular funding from the Operational Infrastructure Support Grant.

\section{Disclosure}

The authors report no disclosures relevant to the manuscript. Go to Neurology.org/ $\mathrm{N}$ for full disclosures.

\section{Publication history}

Received by Neurology June 14, 2018. Accepted in final form October 18, 2018.

Appendix Authors

\begin{tabular}{llll}
\hline Name & Location & Role & Contribution \\
\hline P.J. Buyck & $\begin{array}{l}\text { Leuven, } \\
\text { Belgium }\end{array}$ & Author & $\begin{array}{l}\text { Major role in the } \\
\text { acquisition of data, } \\
\text { revising the manuscript } \\
\text { for intellectual content }\end{array}$ \\
\hline S.M. Zuurbier & $\begin{array}{l}\text { Amsterdam, } \\
\text { the } \\
\text { Netherlands }\end{array}$ & Author & $\begin{array}{l}\text { Major role in the } \\
\text { acquisition of data, } \\
\text { revising the manuscript } \\
\text { for intellectual content }\end{array}$ \\
\hline C.G. Esperon & Newcastle, & Author & $\begin{array}{l}\text { Major role in the } \\
\text { acquisition of data, } \\
\text { revising the manuscript } \\
\text { for intellectual content }\end{array}$ \\
\hline M.A. Barboza & México City, & Author & $\begin{array}{l}\text { Major role in the } \\
\text { acquisition of data, } \\
\text { revising the manuscript } \\
\text { for intellectual content }\end{array}$ \\
\hline P. Costa & México & Author & $\begin{array}{l}\text { Major role in the } \\
\text { acquisition of data }\end{array}$ \\
\hline
\end{tabular}


Appendix (continued)

\begin{tabular}{llll}
\hline Name & Location & Role & Contribution \\
\hline I. Escudero & Seville, Spain & Author & $\begin{array}{l}\text { Major role in the } \\
\text { acquisition of data }\end{array}$ \\
\hline D. Renard & Nîmes, & Author & $\begin{array}{l}\text { Major role in the } \\
\text { acquisition of } \\
\text { data, revising the } \\
\text { France }\end{array}$ \\
& & $\begin{array}{l}\text { manscript for } \\
\text { intellectual content }\end{array}$ \\
\end{tabular}

\begin{tabular}{|c|c|c|c|}
\hline R. Lemmens & $\begin{array}{l}\text { Leuven, } \\
\text { Belgium }\end{array}$ & Author & $\begin{array}{l}\text { Revising the manuscript } \\
\text { for intellectual content }\end{array}$ \\
\hline N. Hinteregger & Graz, Austria & Author & $\begin{array}{l}\text { Major role in the } \\
\text { acquisition of data, } \\
\text { revising the manuscript } \\
\text { for intellectual content }\end{array}$ \\
\hline F. Fazekas & Graz, Austria & Author & $\begin{array}{l}\text { Major role in the } \\
\text { acquisition of } \\
\text { data, revising the } \\
\text { manuscript for } \\
\text { intellectual content }\end{array}$ \\
\hline
\end{tabular}

\begin{tabular}{lll}
\hline J. Jimenez Conde & $\begin{array}{l}\text { Barcelona, Author } \\
\text { Spain }\end{array}$ & $\begin{array}{l}\text { Major role in the } \\
\text { acquisition of data, } \\
\text { revising the manuscrip }\end{array}$ \\
&
\end{tabular}

\begin{tabular}{lll}
\hline E. Giralt- & Barcelona, Author & Major role in the \\
Steinhauer & Spain & $\begin{array}{l}\text { acquisition of data, } \\
\text { revising the manuscript }\end{array}$ \\
& & for intellectual content
\end{tabular}

\begin{tabular}{|c|c|c|c|}
\hline S. Hiltunen & $\begin{array}{l}\text { Helsinki, } \\
\text { Finland }\end{array}$ & Author & $\begin{array}{l}\text { Major role in the } \\
\text { acquisition of data }\end{array}$ \\
\hline A. Arauz & $\begin{array}{l}\text { México City, } \\
\text { México }\end{array}$ & Author & $\begin{array}{l}\text { Revising the manuscript } \\
\text { for intellectual content }\end{array}$ \\
\hline A. Pezzini & Brescia, Italy & Author & $\begin{array}{l}\text { Revising the manuscript } \\
\text { for intellectual content }\end{array}$ \\
\hline J. Montaner & Seville. Spain & Author & $\begin{array}{l}\text { Revising the manuscript } \\
\text { for intellectual content }\end{array}$ \\
\hline J. Putaala & $\begin{array}{l}\text { Helsinki, } \\
\text { Finland }\end{array}$ & Author & $\begin{array}{l}\text { Revising the } \\
\text { manuscript for } \\
\text { intellectual content }\end{array}$ \\
\hline C. Weimar & $\begin{array}{l}\text { Essen, } \\
\text { Germany }\end{array}$ & Author & $\begin{array}{l}\text { Revising the manuscript } \\
\text { for intellectual content }\end{array}$ \\
\hline L. Churilov & $\begin{array}{l}\text { Melbourne, } \\
\text { Australia }\end{array}$ & Author & $\begin{array}{l}\text { Analysis or } \\
\text { interpretation of the } \\
\text { data }\end{array}$ \\
\hline
\end{tabular}

\begin{tabular}{lll}
\hline T. Gattringer Graz, Austria Author $\quad \begin{array}{l}\text { Major role in the } \\
\text { acquisition of data, } \\
\text { Revising the manuscript }\end{array}$ \\
\end{tabular}
for intellectual content

\begin{tabular}{|c|c|c|c|}
\hline H. Asadi & $\begin{array}{l}\text { Melbourne, } \\
\text { Australia }\end{array}$ & Author & $\begin{array}{l}\text { Major role in the } \\
\text { acquisition of data }\end{array}$ \\
\hline T. Tatlisumak & $\begin{array}{l}\text { Gothenburg, } \\
\text { Sweden }\end{array}$ & Author & $\begin{array}{l}\text { Design or } \\
\text { conceptualization of the } \\
\text { study, revising the } \\
\text { manuscript for } \\
\text { intellectual content }\end{array}$ \\
\hline J.M. Coutinho & $\begin{array}{l}\text { Amsterdam, } \\
\text { the } \\
\text { Netherlands }\end{array}$ & Author & $\begin{array}{l}\text { Design or } \\
\text { conceptualization of the } \\
\text { study, revising the } \\
\text { manuscript for } \\
\text { intellectual content }\end{array}$ \\
\hline
\end{tabular}

Appendix (continued)

\begin{tabular}{|c|c|c|c|}
\hline Name & Location & Role & Contribution \\
\hline P. Demaerel & $\begin{array}{l}\text { Leuven, } \\
\text { Belgium }\end{array}$ & Author & $\begin{array}{l}\text { Design or } \\
\text { conceptualization of the } \\
\text { study, revising the } \\
\text { manuscript for } \\
\text { intellectual content }\end{array}$ \\
\hline V. Thijs & $\begin{array}{l}\text { Melbourne, } \\
\text { Australia }\end{array}$ & Author & $\begin{array}{l}\text { Design or } \\
\text { conceptualization of the } \\
\text { study, analysis or } \\
\text { interpretation of the } \\
\text { data, drafting the } \\
\text { manuscript for } \\
\text { intellectual content }\end{array}$ \\
\hline
\end{tabular}

\section{References}

1. Silvis SM, de Sousa DA, Ferro JM, Coutinho JM. Cerebral venous thrombosis. Nat Rev Neurol 2017;13:555-565.

2. Bousser MG, Ferro JM. Cerebral venous thrombosis: an update. Lancet Neurol 2007; 6:162-170.

3. Alons IME, Goudsmit BFJ, Jellema K, van Walderveen MAA, Wermer MJH, Algra A. Yield of computed tomography (CT) angiography in patients with acute headache, normal neurological examination, and normal non contrast CT: a meta-analysis. J Stroke Cerebrovasc Dis 2018;27:1077-1084.

4. Devasagayam S, Wyatt B, Leyden J, Kleinig T. Cerebral venous sinus thrombosis incidence is higher than previously thought: a retrospective population-based study. Stroke 2016;47:2180-2182.

5. Ferro JM, Canhão P, Stam J, et al. Delay in the diagnosis of cerebral vein and dural sinus thrombosis: influence on outcome. Stroke 2009;40:3133-3138.

6. Liberman AL, Gialdini G, Bakradze E, Chatterjee A, Kamel H, Merkler AE. Misdiagnosis of cerebral vein thrombosis in the emergency department. Stroke $2018 ; 49$ 1504-1506.

7. Saposnik G, Barinagarrementeria F, Brown RD Jr, et al. Diagnosis and management of cerebral venous thrombosis: a statement for healthcare professionals from the American Heart Association/American Stroke Association. Stroke 2011;42: 1158-1192.

8. Ferro JM, Bousser MG, Canhão $P$, et al. European Stroke Organization guideline for the diagnosis and treatment of cerebral venous thrombosis: en dorsed by the European Academy of Neurology. Eur J Neurol 2017;24: 1203-1213.

9. Black DF, Rad AE, Gray LA, Campeau NG, Kallmes DF. Cerebral venous sinus density on noncontrast CT correlates with hematocrit. AJNR Am J Neuroradiol 2011; 32:1354-1357.

10. Roland T, Jacobs J, Rappaport A, Vanheste R, Wilms G, Demaerel P. Unenhanced brain $\mathrm{CT}$ is useful to decide on further imaging in suspected venous sinus thrombosis. Clin Radiol 2010;65:34-39.

11. Buyck PJ, De Keyzer F, Vanneste D, Wilms G, Thijs V, Demaerel P. CT density measurement and $\mathrm{H}: \mathrm{H}$ ratio are useful in diagnosing acute cerebral venous sinus thrombosis. AJNR Am J Neuroradiol 2013;34:1568-1572.

12. Besachio DA, Quigley EP III, Shah LM, Salzman KL. Noncontrast computed tomographic Hounsfield unit evaluation of cerebral venous thrombosis: a quantitative evaluation. Neuroradiology 2013;55:941-945.

13. Zaheer S, Iancu D, Seppala N, et al. Quantitative non-contrast measurements improve diagnosing dural venous sinus thrombosis. Neuroradiology 2016;58:657-663.

14. Avsenik J, Oblak JP, Popovic KS. Non-contrast computed tomography in the diagnosis of cerebral venous sinus thrombosis. Radiol Oncol 2016;50:263-268.

15. Poon CS, Chang JK, Swarnkar A, Johnson MH, Wasenko J. Radiologic diagnosis of cerebral venous thrombosis: pictorial review. AJR Am J Roentgenol 2007;189: S64-S75.

16. Coutinho JM, van den Berg R, Zuurbier SM, et al. Small juxtacortical hemorrhages in cerebral venous thrombosis. Ann Neurol 2014;75:908-916.

17. Leach JL, Fortuna RB, Jones BV, Gaskill-Shipley MF. Imaging of cerebral venous thrombosis: current techniques, spectrum of findings, and diagnostic pitfalls. Radiographics 2006;26(suppl 1):S19-S41; discussion S42-S43.

18. Buderer NM. Statistical methodology: I: incorporating the prevalence of disease into the sample size calculation for sensitivity and specificity. Acad Emerg Med 1996;3:895-900.

19. Pencina MJ, D'Agostino RB Sr, D'Agostino RB Jr, Vasan RS. Evaluating the added predictive ability of a new marker: from area under the ROC curve to reclassification and beyond. Stat Med 2008;27:157-172; discussion 207-212.

20. Pepe $\mathrm{M}$, Longton $\mathrm{G}$, Janes $\mathrm{H}$. Estimation and comparison of receiver operating characteristic curves. Stata J 2009;9:1.

21. Leeflang MM, Bossuyt PM, Irwig L. Diagnostic test accuracy may vary with prevalence: implications for evidence-based diagnosis. J Clin Epidemiol 2009;62: 5-12. 
22. Linn J, Pfefferkorn T, Ivanicova K, et al. Noncontrast CT in deep cerebral venous thrombosis and sinus thrombosis: comparison of its diagnostic value for both entities. AJNR Am J Neuroradiol 2009;30:728-735.

23. New PF, Aronow S. Attenuation measurements of whole blood and blood fractions in computed tomography. Radiology 1976;121:635-640.

24. Kirchhof K, Welzel T, Mecke C, Zoubaa S, Sartor K. Differentiation of white, mixed, and red thrombi: value of $\mathrm{CT}$ in estimation of the prognosis of thrombolysis phantom study. Radiology 2003;228:126-130.
25. Al Bunyan M, Ogunniyi A. Incidental cerebral venous thrombosis in a patient with multiple sclerosis. J Neurol Sci 1997;149:191-194.

26. Alons IM, Jellema K, Wermer MJ, Algra A. D-dimer for the exclusion of cerebral venous thrombosis: a meta-analysis of low risk patients with isolated headache. BMC Neurol 2015;15:118.

27. Crassard I, Soria C, Tzourio C, et al. A negative D-dimer assay does not rule out cerebral venous thrombosis: a series of seventy-three patients. Stroke 2005;36: $1716-1719$ 


\section{Neurology}

\section{Diagnostic accuracy of noncontrast CT imaging markers in cerebral venous thrombosis}

Pieter-Jan Buyck, Susanna M. Zuurbier, Carlos Garcia-Esperon, et al.

Neurology 2019;92;e841-e851 Published Online before print January 18, 2019

DOI 10.1212/WNL.0000000000006959

\section{This information is current as of January 18, 2019}

\section{Updated Information \& Services}

References

Subspecialty Collections

Permissions \& Licensing

Reprints including high resolution figures, can be found at: http://n.neurology.org/content/92/8/e841.full

This article cites 27 articles, 8 of which you can access for free at: http://n.neurology.org/content/92/8/e841.full\#ref-list-1

This article, along with others on similar topics, appears in the following collection(s):

Case control studies

http://n.neurology.org/cgi/collection/case_control_studies

Cerebral venous thrombosis

http://n.neurology.org/cgi/collection/cerebral_venous_thrombosis CT

http://n.neurology.org/cgi/collection/ct

Secondary headache disorders

http://n.neurology.org/cgi/collection/secondary_headache_disorders

Information about reproducing this article in parts (figures,tables) or in its entirety can be found online at:

http://www.neurology.org/about/about_the_journal\#permissions

Information about ordering reprints can be found online:

http://n.neurology.org/subscribers/advertise

Neurology ${ }^{\circledR}$ is the official journal of the American Academy of Neurology. Published continuously since 1951, it is now a weekly with 48 issues per year. Copyright @ 2019 American Academy of Neurology. All rights reserved. Print ISSN: 0028-3878. Online ISSN: 1526-632X.

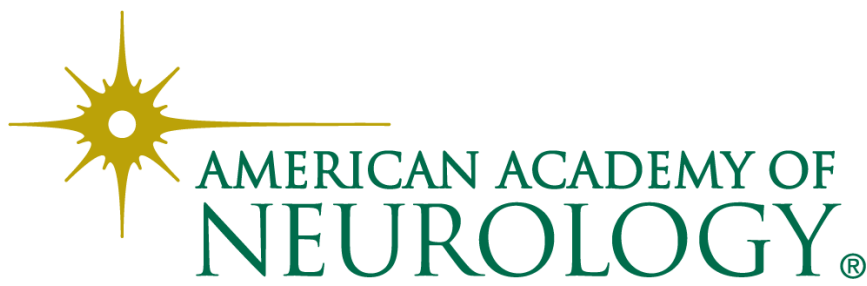

